\title{
Resistance-inducing chemicals against Colletotrichum gloeosporioides in mango ${ }^{1,2}$
}

\author{
Juan A. Santiago ${ }^{3}$,Lydia I. Rivera-Vargas ${ }^{4}$, \\ Rocío del P. Rodríguez ${ }^{5}$ and Raúl Macchiavelli ${ }^{6}$
}

J. Agric. Univ. P.R. 90(3-4):221-235 (2006)

\begin{abstract}
Various resistance-inducing chemicals were assessed in the interaction between mango (Mangifera indica $L$.) and the anthracnose pathogen Colletotrichum gloeosporioides. These were salicylic acid, isonicotinic acid, benzo $(1,2,3)$ thiadiazole-7-carbothionic acid S-methyl ester (Actigard®), and other chemical compounds structurally similar, such as nicotinic acid, nicotinic acid adenine dinucleotide, isonicotinic acid ethyl ester, $\mathrm{N}$-oxide isonicotinic acid, benzoic acid and sodium benzoate. No significant differences $(P>0.05)$ in C. gloeosporioides colony growth were detected on culture media amended with the different resistance-inducing chemicals evaluated. At laboratory conditions, these compounds were sprayed to runoff on mango leaves and fruit pieces prior to inoculation. Lesion size was significantly reduced $(P>0.10)$ by concentrations ranging from $10^{-12} \mathrm{M}$ to $10^{-6}$ $\mathrm{M}$ of salicylic acid (SA), $10^{-18} \mathrm{M}$ and $10^{-14} \mathrm{M}$ of isonicotinic acid (INA), $10^{-17} \mathrm{M}$ to $10^{-2} \mathrm{M}$ of Actigard $\mathrm{Q}$, and $10^{-10} \mathrm{M}$ benzoic acid (BA). Salicylic acid, INA and BA caused toxicity on leaves at concentrations ranging from $10^{-1}$ to $10^{-3} \mathrm{M}$. Chemical compounds that induced resistance at laboratory conditions were further evaluated on six-month-old mango seedlings in a shade house. None of the chemicals tested significantly $(P>0.05)$ reduced lesion size caused by C. gloeosporioides. Other resistance-inducing chemicals not tested during these studies, such as probenazole, cyclopropane carboxylic acid derivatives, non-protein amino acids [ $\beta$-aminobutyric acid (BABA) and $\gamma$-aminobutyric acid (GABA)] and Phytoguard $\otimes$, should be evaluated individually and in combinations to clarify this lack of induced resistance in mango tissues.
\end{abstract}

${ }^{1}$ Manuscript submitted to Editorial Board 13 December 2005.

${ }^{2}$ This research was supported by a United States Department of Agriculture, Tropical and Subtropical Agricultural Research (T-STAR-76) grant in collaboration with the Department of Plant Pathology, University of Florida in Bradenton, and the Department of Crop Protection, University of Puerto Rico, Mayagüez Campus. We thank all reviewers for their time and effort.

${ }^{3}$ Former graduate student, Department of Crop Protection, P.O. Box 9030, University of Puerto Rico-Mayagüez Campus, Mayagüez, PR 00681-9030.

${ }^{4}$ Professor, Department of Crop Protection, P.O. Box 9030, University of Puerto RicoMayagüez Campus, Mayagüez, PR 00681-9030; e-mail: lyrivera@uprm.edu.

${ }^{5}$ Plant Pathologist, Ad-Honorem, Department of Crop Protection.

${ }^{6}$ Professor, Department of Agronomy and Soils.

Trade names are mentioned to provide specific information and do not constitute a warranty of equipment or material by the University of Puerto Rico, nor is this mention a statement of preference over other equipment or materials. 
Key words: anthracnose, Colletotrichum gloeosporioides, mango, induced resistance, salicylic acid, isonicotinic acid, benzoic acid, Actiguard®

\title{
RESUMEN
}

\section{Compuestos químicos inductores de resistencia contra Colletotrichum gloeosporioides en mangó}

\begin{abstract}
Se evaluaron varios compuestos químicos inductores de resistencia en la interacción entre mangó (Mangifera indica L.) y el patógeno, agente causal de la antracnosis, Colletotrichum gloeosporioides. Los compuestos evaluados fueron ácido salicílico, ácido isonicotínico, ácido benzo $(1,2,3)$ tiadiazol-7-carbotiónico éster de S-metilo (Actigard®) y otros compuestos químicos estructuralmente similares como el ácido nicotínico, el dinucleótido de adenina de ácido nicotínico, el éster de etilo del ácido isonicotínico, el $\mathrm{N}$-óxido de ácido isonicotínico, el ácido benzoico y el benzoato de sodio. En el laboratorio antes de la inoculación, estos compuestos se asperjaron hasta la saturación sobre pedazos de hojas y frutas de mangó. En condiciones de laboratorio, el tamaño de las lesiones causadas por C. gloeosporioides en pedazos de hojas y frutas de mangó se redujo significativamente $(P$ $<0.10$ ) a concentraciones que fluctuaron entre $10^{-12} \mathrm{M}$ a $10^{-6} \mathrm{M}$ de ácido salicílico (SA), $10^{-18} \mathrm{M}$ y $10^{-14} \mathrm{M}$ de ácido isonicotínico (INA), $10^{-17} \mathrm{M}$ a $10^{-2} \mathrm{M}$ de Actigard® y $1^{-10} \mathrm{M}$ de ácido benzoico (BA). El ácido salicílico, INA y BA causaron toxicidad en las hojas a concentraciones que fluctuaron entre $10^{-1}$ a $10^{-3} \mathrm{M}$. Los compuestos químicos que indujeron resistencia en condiciones de laboratorio se evaluaron en árboles de mangó de seis meses de edad en condiciones de umbráculo. Ninguno de los compuestos químicos evaluados redujo significativamente $(\mathrm{P}<0.05)$ el tamaño de la lesión causada por c. gloeosporioides. Otros agentes químicos inductores de resistencia que no fueron evaluados durante estos estudios, tales como probenazol, derivados ciclopropanos de ácido carboxílico, aminoácidos no-proteícos [ $\beta$-ácido aminobutírico (BABA) y $\gamma$-ácido aminobutírico (GABA)] y Phytogard®, se deben evaluar individualmente y en combinación para clarificar la ausencia de inducción de resistencia en los tejidos del mangó.
\end{abstract}

Palabras clave: antracnosis, Colletotrichum gloeosporioides, mangó, resistencia inducida, ácido salicílico, ácido isonicotínico, ácido benzoico, Actiguard®

\section{INTRODUCTION}

Commercial mango (Mangifera indica L.) production contributes $\$ 12$ million to Puerto Rico's annual gross agricultural income. More than $70 \%$ of the island's mango production is exported to Europe, Canada, and to the United States (Anonymous, 2006). In Puerto Rico, as in other production areas, mangos are affected by Colletotrichum gloeosporioides, the causal agent of anthracnose (Arauz, 2000; Bailey and Jeger, 1992; Ploetz, 1994). Typically, C. gloeosporioides [(Penz.) Penz. \& Sacc.] [teleomorph Glomerella cingulata (Stoneman) Spauld. \& Schrenk] directly reduces fruit quantity and quality, especially in hot humid tropical environments, where incidence can reach $100 \%$ (Arauz, 2000). Damage to shoot tissues and flowers reduces vigor, and productivity losses regularly force producers to apply costly chemical control measures.

Efforts are under way to reduce the producer's dependence on fungicides to control anthracnose. Novel disease management strategies 
currently being tested may include resistance-inducing chemicals (i.e., non-fungitoxic chemicals) or biological agents that activate mango's natural defense mechanisms against threatening pathogens (Karba and Kuc, 1999; Ishii et al., 1999; Colón et al., 2002). Resistance induction mechanisms are ideally systemically activated and characterized by broad-spectrum disease resistance.

Previous investigations with mango have demonstrated that biological agents such as hypovirulent $C$. gloeosporioides isolates induced resistance in detached fruits and three-month-old seedlings. However, the response was elusive and the signals, conditions, and mechanisms involved needed to be identified (Colón et al., 2002; Lugo, 2001).

Phenolic compounds such as salicylic acid and isonicotinic acid have been extensively studied as resistance-inducing chemical agents in plants, but very little research has been done with fruit trees (Kessmann et al., 1994; Hammerschmidt and Smith-Becker, 1999; Tally et al., 1999). Studies have mainly been focused on herbaceous plants in which high levels of salicylic acid have been reported after infection with a pathogen (Malamy et al., 1990; Metraux et al., 1990, 1991; Uknes et al., 1992). These studies have led to the development of Actigard ${ }^{\circledR}$, the first plant activator or chemical inductor commercially available (Tally et al., 1999). This compound is a benzo $(1,2,3)$ thiadiazole-7-carbothionic acid Smethyl ester or BTH, used as foliar spray in order to induce the accumulation of pathogenesis-related proteins and to reduce disease incidence in many important crops (Gorlach et al., 1996; Tally et al., 1999).

There are very few reports dealing with resistance-inducing chemical agents in tropical fruit trees. In temperate zones such as Japan, Ishii et al. (1999) reported that neither black spot caused by Alternaria alternata in Japanese pear nor grey mold caused by Botrytis cinerea in grapevine was controlled with Actigard ${ }^{\circledR}$. They discussed the possibility of different mechanisms of pathogenicity in fungi, such as the production of toxins by $A$. alternata, as a factor that might limit product effectiveness in the induction of resistance in pears. In Hawaii, Zhu et al. (2000) reported that $15 \mathrm{mM}$ salicylic acid induced resistance in young papaya plants and $1 \mathrm{mM} \mathrm{BTH}$ increased papaya resistance to Phytophthora palmivora. However, the authors reported that BTH was slightly toxic to seedlings even though it gave complete protection against the pathogen.

This research examined the potential of various resistance-inducing chemical agents such as salycilic acid, isonicotinic acid, Actigard $®$ and other structurally similar chemical compounds against anthracnose in mango. The study sought to provide helpful insights on the induction of localized and systemic resistance against C. gloeosporioides in mango tissues. 


\section{MATERIALS AND METHODS}

\section{Fungal Isolates and Source of Inoculum}

Colletotrichum gloeosporioides was isolated from natural anthracnose lesions in mango fruits cv. Keitt from Mayagüez, Puerto Rico, on potato dextrose agar (PDA), acidified with $25 \%$ lactic acid (APDA) at $27^{\circ} \mathrm{C}$. A continuous source of C. gloeosporioides inoculum was kept on disinfested mango leaves in humid chambers at the laboratory. Masses of orange conidia produced in an acervulus were used to isolate the pathogen in APDA for further experimentation.

\section{In vitro Test of Chemical Inducers}

An in vitro experiment was conducted to evaluate the effect on C. gloeosporioides of various resistance-inducing chemicals such as salicylic acid (SA), isonicotinic acid (INA), benzoic acid (BA) and Actigard ${ }^{\circledR}$. Potato dextrose agar was amended with $10^{-1} \mathrm{M}$ (the highest concentration evaluated) of the different resistance-inducing chemicals. Non-amended PDA was used as the control. Mycelial disks (4 mm) from 7-day-old C. gloeosporioides cultures were placed on the center of the plates and incubated at $27^{\circ} \mathrm{C}$. Three replicates per each treatment were made. A week after inoculation, colony growth (diameter in $\mathrm{cm}$ ) was measured. Tukey's test was used to separate means $(\alpha=0.05)$.

\section{Localized Chemical Induction on Detached Mango Leaves and Fruit Pieces}

Three experiments were designed under laboratory conditions to determine whether localized resistance could be induced by different chemicals in detached mango (cv. Keitt) leaves and fruit pieces. Each experiment will be further described in detail.

All detached mango tissues (fruit or leaf pieces) were superficially sterilized with ethanol (70\%) and sodium hypochlorite $(0.5 \%)$, rinsed with sterile deionized distilled water for 1 min each. All promising resistance-inducing chemicals were mixed with sterile deionized distilled water to reach desired concentration, and sprayed to runoff on tissues 24,36 and $48 \mathrm{~h}$ prior to inoculation with the fungal pathogen. Control tissues were sprayed with sterile deionized distilled water.

For C. gloeosporioides inoculation, mycelial plugs (4 $\mathrm{mm}$ in diameter) from seven-day-old fungal cultures were placed on mango tissues, with or without wounding. Wounds were inflicted with a sterile dissection needle. Acidified PDA disks were placed in control treatments. Treated mango tissues (leaf or fruit pieces) were placed in humid chambers that consisted of petri plates $(100 \times 15 \mathrm{~mm})$ placed inside plastic boxes $(91 \times 41 \times 15 \mathrm{~cm})$ under high humidity (i.e., 100 to $90 \%)$ at $25^{\circ} \mathrm{C}$. 
A week after inoculation, lesion size $(\mathrm{cm})$ was measured. Treatments were replicated three times for each experiment.

Percentage of reduction or increase ( $r$ or $i$ ) in lesion size for all experiments was calculated as follows:

First, we calculated the reduction or increase $(r$ or $i)$ in lesion size:

$r$ or $i=$ Control mean lesion size - Treated tissue mean lesion size

Second, we calculated the percentage of reduction or increase ( $r$ or $i)$ in lesion size:

$$
\%=(r \text { or } i / \text { Control mean lesion size }) \times 100
$$

First experiment: Salicylic acid, INA and Actigard ${ }^{\circledR}$ were tested on detached mango leaf pieces $(10 \times 7.5 \mathrm{~cm})$. Six different Actigard® concentrations were tested, ranging from $1 \times 10^{-4} \mathrm{M}$ to $6 \times 10^{-4} \mathrm{M}$. For SA and INA, nine concentrations were tested ranging from $10^{-4}$ to $10^{-12} \mathrm{M}$.

Second experiment: In addition to SA, INA and Actigard $\mathbb{B}$, six other compounds structurally similar to INA and SA were tested on mango fruit pieces $(11 \times 6 \mathrm{~cm})$. Tissues were sprayed to run-off (aprox. $2.3 \mathrm{ml}$ ) with each chemical compound concentration tested. These were nicotinic acid, nicotinic acid adenine dinucleotide, isonicotinic acid ethyl ester, $\mathrm{N}$-oxide isonicotinic acid, benzoic acid (BA) and sodium benzoate. Nine concentrations were examined for each chemical tested, ranging from $10^{-10}$ to $10^{-18} \mathrm{M}$.

Third experiment: Salicylic acid, BA, INA and Actigard ${ }^{\circledR}$ were further evaluated on leaf pieces $(10 \times 7.5 \mathrm{~cm})$ with six different concentrations ranging from $10^{-1}$ to $10^{-8} \mathrm{M}$.

\section{Systemic Chemical Induction on Mango Seedlings}

Two experiments were designed to examine the induction of resistance by different chemical compounds against $C$. gloeosporioides in sixmonth-old mango seedlings under shade house conditions. Seedlings were trimmed and new leaf size was measured in order to standardize leaf age in each experimental block. Seedlings were never treated with a systemic fungicide or any other chemical before experimentation. Selection of the chemical inducers and concentrations tested was based on findings of laboratory trials on detached mango leaves and fruits. The following resistance-inducing chemical agents were spayed to runoff on seedling foliage: SA $\left(10^{-7}\right)$, INA $\left(10^{-14}\right)$, BA $\left(10^{-10}\right)$ and Actigard® $\left(10^{-4}\right)$. Experiments were conducted from April to September, 2001, months when precipitation and high humidity prevail. 
First experiment: Seven-day-old mycelial disks $(4 \mathrm{~mm})$ of $C$. gloeosporioides were used to inoculate new leaves of mango seedlings (cv. Keitt grafted on 'Pasote'), 24, 96 and $168 \mathrm{~h}$ after chemical induction. Inoculum was applied, with and without wounding as previously described, on two different new leaves. Each leaf was inoculated twice. Acidified PDA disks were used as inoculum controls. Seedlings were placed in a walk-in humid chamber $(18 \times 30 \times 30 \mathrm{~m})$ at $100 \% \mathrm{RH}$ and $26^{\circ} \mathrm{C}$ for $72 \mathrm{~h}$. Then seedlings were transferred to benches in the shade-house and lesion size (cm) was measured daily for 12 days.

Second experiment: The experiment was conducted as described above with the exception that mango cv. Keitt was grafted on 'Mayagüezano' and the timing of new leaf growth was monitored to standardize experimental blocks. Time interval between the applications of the resistance-inducing chemical agent prior to pathogen inoculation was modified. Leaves were inoculated with C. gloeosporioides 24, 72 and 168 $\mathrm{h}$ after chemical induction. Mango seedlings were kept in the shade house for 20 days for monitoring disease development.

\section{Statistical Analysis and Experimental Design}

Localized chemical induction (Laboratory experiments): A randomized complete block design was used in all experiments conducted under laboratory conditions. Treatments were replicated three times. The equation used was $\mathbf{Y}_{\mathrm{ij}}=\boldsymbol{\mu}+\boldsymbol{\alpha}_{\mathbf{i}}+\boldsymbol{\beta}_{\mathrm{j}}+\boldsymbol{\varepsilon}_{\mathrm{ij}} ; \mathbf{Y}_{\mathrm{ij}}$ is the individual response of the variable measured (i.e., lesion size in $\mathrm{cm}$ ); $\boldsymbol{\mu}$ is the general mean; $\boldsymbol{\alpha}_{\mathbf{i}}$ is the treatment effect; $\boldsymbol{\beta}_{\mathbf{j}}$ is the block effect; $\boldsymbol{\varepsilon}_{\mathrm{ij}}$ is the experimental error. Blocks were represented by each humid chamber (i.e., plastic boxes) in which the various treatments (i.e., resistance-inducing chemicals and sterile distilled water) were placed at random.

Statistical analysis was performed by a linear general model using SAS, and Dunnett's test was used to compare means of each treatment with the control using $\alpha=0.10$.

Systemic chemical induction, experiments conducted under shade house conditions using six-month-old mango seedlings: We used a factorial design $5 \times 3$ (five concentrations and three time intervals) of a randomized complete block with treatments replicated three times. The equation used was $\mathbf{Y}_{\mathrm{ijkl}}=\boldsymbol{\mu}+\boldsymbol{\alpha}_{\mathrm{i}}+\boldsymbol{\beta}_{\mathbf{j}}+\boldsymbol{\gamma}_{\mathbf{k}}+\boldsymbol{\alpha} \boldsymbol{\beta}_{\mathrm{ij}}+\varepsilon_{\mathrm{ijk} \mathbf{l}} ; \mathbf{Y}_{\mathrm{ijkl}}$ is the individual response of the variable measured (i.e., lesion size in $\mathrm{cm}$ ); $\boldsymbol{\mu}$ is the general mean; $\boldsymbol{\alpha}_{\mathbf{i}}$ is the treatment effect at level $\mathbf{i} ; \boldsymbol{\beta}_{\mathbf{j}}$ is the inoculation time effect at level $\mathbf{j} ; \gamma_{\mathbf{k}}$ is the block effect; $\varepsilon_{\mathbf{i j k l}}$ is the experimental error. Blocks were represented by benches in the shade house; treatments were placed at random. Statistical analysis was performed by a linear general model using SAS and Dunnett's test as described above using $\alpha=0.05$. 


\section{RESULTS}

\section{In vitro Test of Chemical Inducers}

No significant differences $(\mathrm{P}>0.05)$ in C. gloeosporioides colony growth (diameter in $\mathrm{cm}$ ) were detected on APDA amended with SA, INA, BA and Actigard ${ }^{\circledR}$ using Tukey's test at $\alpha=0.05$. Mean colony growth ranged from 6.0 to $6.5 \mathrm{~cm}$ in diameter for the four resistanceinducing chemicals evaluated.

\section{Localized Chemical Induction on Detached Mango Leaves and Fruit Pieces}

First Experiment: Salicylic acid showed a significant reduction in lesion size ( 32 to $36 \%$ ) when sprayed on leaves $48 \mathrm{~h}$ previous to pathogen inoculation at concentrations ranging from $10^{-6}$ to $10^{-12}$ (Table 1). Neither INA nor Actigard® significantly reduced lesion size compared to that of controls at any time intervals tested. On the contrary, lesion size increased up to $93 \%$ when tissues were treated with Actigard ${ }^{\circledR} 36$ $\mathrm{h}$ before inoculation at concentrations of $10^{-4}$. Lesions did not develop in leaf tissue inoculated without wounding during this experiment.

Second experiment: Compounds similar in structure to SA and INA were assessed as resistance inducers in mango fruit pieces. Contrary to the first experiment, lesions developed in unwounded tissues, but lesions, ranging from 0.60 to $2.40 \mathrm{~mm}$, were smaller than those observed in wounded tissues ( 1.33 to $2.43 \mathrm{~mm}$ ). Concentrations of $10^{-14}$ and $10^{-18}$ of INA caused 28 and $73 \%$ reduction in lesion size when applied $24 \mathrm{~h}$ (with wounding) and $36 \mathrm{~h}$ (without wounding) previous to pathogen inoculation, respectively (Table 2B). Actiguard ${ }^{\circledR}$ also significantly reduced lesion size up to $42 \%$ at concentration of $10^{-17}$ when applied 24 $\mathrm{h}$ previous to pathogen inoculation (without wounding) (Table 2C). Salicylic acid was not as effective when applied to fruits as when applied to the leaves.

No other phenolic compounds tested that were derivatives of SA and INA induced resistance under the laboratory conditions tested (data not shown) except for BA (Table 2D). Benzoic acid caused 90 to $100 \%$ reduction in lesion size at concentrations ranging from $10^{-10}$ to $10^{-17}$ when applied $48 \mathrm{~h}$ previous to inoculation (without wounding) (Table 2D). When tissues were inoculated $24 \mathrm{~h}$ after application of benzoic acid we observed an increase in lesion size up to $98 \%$ in wounded fruits.

Third experiment: When higher concentrations of selected compounds were tested, we observed that SA, INA and BA caused toxicity on leaves at concentrations ranging from $10^{-1}$ to $10^{-3} \mathrm{M}$. Necrotic areas were observed at leaf edges and over the whole leaf. Among all chemicals tested, Actigard® was the only compound that did not show 
TABLE 1. Percentage of reduction (-) or increase (+) in lesion size in detached mango leaves, compared to that of controls, after the application of potential resistance-inducing chemicals at three time intervals $(24,36$ and $48 \mathrm{~h}$ ) before Colletotrichum gloeosporioides inoculation (First Experiment).

\begin{tabular}{|c|c|c|c|c|c|c|c|c|c|}
\hline \multirow[b]{4}{*}{ Concentration } & \multicolumn{9}{|c|}{ Percentage of reduction (-) or increase $(+)$ in lesion size ${ }^{1}$} \\
\hline & \multicolumn{9}{|c|}{$\mathrm{Time}^{2}$} \\
\hline & \multicolumn{3}{|c|}{$24 \mathrm{~h}$} & \multicolumn{3}{|c|}{$36 \mathrm{~h}$} & \multicolumn{3}{|c|}{$48 \mathrm{~h}$} \\
\hline & $\mathrm{SA}$ & INA & $\operatorname{Act}(\mathbb{2}$ & SA & INA & Act@ & SA & INA & $\operatorname{Act} \circledast$ \\
\hline $1 \times 10^{-12}$ & -7 & -12 & $\mathrm{NE}^{3}$ & -8 & -7 & NE & $-36^{*}$ & +23 & $\mathrm{NE}$ \\
\hline $1 \times 10^{-11}$ & -7 & -3 & NE & -3 & +7 & NE & -18 & +8 & NE \\
\hline $1 \times 10^{-10}$ & -7 & -3 & $\mathrm{NE}$ & -8 & +20 & $\mathrm{NE}$ & $-34^{*}$ & -4 & $\mathrm{NE}$ \\
\hline $1 \times 10^{-9}$ & -2 & +12 & $\mathrm{NE}$ & +8 & +13 & $\mathrm{NE}$ & $-34^{*}$ & -8 & $\mathrm{NE}$ \\
\hline $1 \times 10^{-8}$ & +2 & +12 & $\mathrm{NE}$ & 00 & 00 & $\mathrm{NE}$ & -23 & +35 & $\mathrm{NE}$ \\
\hline $1 \times 10^{-7}$ & -5 & -18 & $\mathrm{NE}$ & 00 & +7 & $\mathrm{NE}$ & $-32 *$ & 00 & $\mathrm{NE}$ \\
\hline $1 \times 10^{-6}$ & -14 & -3 & $\mathrm{NE}$ & 00 & -7 & $\mathrm{NE}$ & $-34^{*}$ & +15 & NE \\
\hline $1 \times 10^{-5}$ & -2 & +32 & $\mathrm{NE}$ & 13 & +27 & $\mathrm{NE}$ & -23 & -4 & $\mathrm{NE}$ \\
\hline $1 \times 10^{-4}$ & -2 & -3 & +37 & +8 & -10 & +93 & -25 & -15 & +13 \\
\hline $2 \times 10^{-4}$ & $\mathrm{NE}$ & $\mathrm{NE}$ & 00 & $\mathrm{NE}$ & $\mathrm{NE}$ & +57 & NE & $\mathrm{NE}$ & +13 \\
\hline $3 \times 10^{-4}$ & $\mathrm{NE}$ & NE & +24 & $\mathrm{NE}$ & $\mathrm{NE}$ & +48 & $\mathrm{NE}$ & $\mathrm{NE}$ & 00 \\
\hline $4 \times 10^{-4}$ & $\mathrm{NE}$ & $\mathrm{NE}$ & +13 & $\mathrm{NE}$ & NE & +30 & NE & $\mathrm{NE}$ & +24 \\
\hline $5 \times 10^{-4}$ & $\mathrm{NE}$ & $\mathrm{NE}$ & +42 & $\mathrm{NE}$ & $\mathrm{NE}$ & +12 & $\mathrm{NE}$ & $\mathrm{NE}$ & +26 \\
\hline $6 \times 10^{-4}$ & $\mathrm{NE}$ & NE & +10.5 & $\mathrm{NE}$ & $\mathrm{NE}$ & +30 & $\mathrm{NE}$ & $\mathrm{NE}$ & +8 \\
\hline
\end{tabular}

${ }^{1}$ Percentage of reduction (-) or increase $(+)$ in lesion size compared to that of controls.

${ }^{2}$ Inoculation time after previous application of salicylic acid (SA), isonicotinic acid (INA) and Actigard® (Act $($ ) . Leaf pieces were wounded with a sterile needle before inoculation using $C$. gloeosporioides mycelial disks ( $4 \mathrm{~mm}$ ).

${ }^{3} \mathrm{NE}=$ not evaluated.

*Lesion size means were statistically different from controls based on Dunnett's test at $\mathrm{P}<0.10$.

toxicity at the concentrations evaluated. Actigard ${ }^{\circledR}$ concentrations of $10^{-8}, 10^{-4}$ and $10^{-2}$ significantly reduced lesion size up to $59 \%$ when applied $36 \mathrm{~h}$ previous to inoculation (Table 3 ).

\section{Systemic Chemical Induction on Mango Seedlings}

None of the resistance-inducing chemicals tested significantly reduced lesion size under shade house conditions in six-month-old mango seedlings (Table 4). Treatment effect on lesion size was erratic. For example, a reduction in lesion size ranging from 64 to $78 \%$ was observed when Actigard ${ }^{\circledR}$ was sprayed on tissues $96 \mathrm{~h}$ prior to inoculation with C. gloeosporioides without wounding. This tendency was observed up to 12 days after inoculation. In contrast, we observed an increase in lesion size ranging from 153 to $270 \%$ with all chemicals tested, eight days after inoculation without wounding. These chemicals were sprayed $24 \mathrm{~h}$ 
TABLE 2. Percentage of reduction (-) or increase (+) in lesion size in detached mango fruits, compared to that of controls, after the application of potential resistance-inducing chemicals at three time intervals $(24,36$ and $48 \mathrm{~h})$ before Colletotrichum gloeosporioides inoculation (Second Experiment).

\begin{tabular}{|c|c|c|c|c|c|c|}
\hline \multirow[b]{4}{*}{ Concentrations (M) } & \multicolumn{6}{|c|}{ Percentage of reduction (-) or increase $(+)$ in lesion size ${ }^{1}$} \\
\hline & \multicolumn{6}{|c|}{$\operatorname{Time}^{2}(\mathrm{~h})$} \\
\hline & \multicolumn{3}{|c|}{ With wounding } & \multicolumn{3}{|c|}{ Without wounding } \\
\hline & 24 & 36 & 48 & 24 & 36 & 48 \\
\hline \multicolumn{7}{|l|}{ A. Salicylic acid } \\
\hline $10^{-18}$ & 00 & -21 & +20 & +48 & -10 & +13 \\
\hline $10^{-17}$ & -18 & +17 & -13 & +61 & +69 & -13 \\
\hline $10^{-16}$ & -13 & +14 & +12 & +17 & -49 & +71 \\
\hline $10^{-15}$ & +6 & +10 & -1 & +31 & +9 & -19 \\
\hline $10^{-14}$ & -9 & +17 & +10 & -11 & +9 & +39 \\
\hline $10^{-13}$ & -9 & -7 & +18 & +56 & +54 & +26 \\
\hline $10^{-12}$ & +6 & +31 & -8 & +14 & +39 & +13 \\
\hline $10^{-11}$ & -27 & +35 & -5 & +25 & +45 & +89 \\
\hline $10^{-10}$ & +9 & -2 & -3 & 00 & +30 & +20 \\
\hline \multicolumn{7}{|l|}{ B. Isonicotinic acid } \\
\hline $10^{-18}$ & +57 & $-28^{*}$ & +34 & -8 & +23 & -9 \\
\hline $10^{-17}$ & +26 & -25 & +35 & +16 & +3 & +55 \\
\hline $10^{-16}$ & +59 & -17 & +21 & +28 & +19 & -36 \\
\hline $10^{-15}$ & +56 & -14 & +52 & -19 & -8 & +63 \\
\hline $10^{-14}$ & -4 & -18 & +20 & $-73^{*}$ & +8 & +43 \\
\hline $10^{-13}$ & +35 & +4 & +82 & -16 & +44 & +6 \\
\hline $10^{-12}$ & +19 & -20 & +24 & +8 & +16 & +55 \\
\hline $10^{-11}$ & +19 & -8 & +16 & +20 & +6 & +42 \\
\hline $10^{-10}$ & +16 & -14 & +34 & -37 & -25 & -21 \\
\hline \multicolumn{7}{|l|}{ C. Actiguard® } \\
\hline $10^{-18}$ & 00 & +15 & +13 & -50 & +70 & +50 \\
\hline $10^{-17}$ & $-43^{*}$ & +15 & +13 & -27 & +61 & +44 \\
\hline $10^{-16}$ & -13 & -9 & -8 & -19 & +10 & +7 \\
\hline $10^{-15}$ & -27 & -12 & -10 & -71 & +14 & +10 \\
\hline $10^{-14}$ & -35 & 00 & 00 & -24 & -82 & -60 \\
\hline $10^{-13}$ & +4 & +13 & +11 & +8 & +30 & +22 \\
\hline $10^{-12}$ & -25 & -3 & -3 & -43 & +94 & +68 \\
\hline $10^{-11}$ & -12 & +13 & +11 & +57 & -8 & -6 \\
\hline $10^{-10}$ & -20 & +15 & +13 & +24 & +23 & +17 \\
\hline \multicolumn{7}{|l|}{ D. Benzoic acid } \\
\hline $10^{-18}$ & +54 & -54 & -45 & -4 & 00 & -80 \\
\hline $10^{-17}$ & +93 & -18 & -28 & -38 & 00 & $-90 *$ \\
\hline
\end{tabular}

Percentage of reduction (-) or increase ( + ) in lesion size compared to that of control.

2Time of inoculation after previous application of chemical inducer.

*Lesion size means were statistically different from controls based on Dunnett's test at $\mathrm{P}<0.10$. 
TABLE 2. (Continued) Percentage of reduction (-) or increase (+) in lesion size in detached mango fruits, compared to that of controls, after the application of potential resistance-inducing chemicals at three time intervals $(24,36$ and $48 \mathrm{~h}$ ) before Colletotrichum gloeosporioides inoculation (Second Experiment).

\begin{tabular}{|c|c|c|c|c|c|c|}
\hline \multirow[b]{4}{*}{ Concentrations $(\mathrm{M})$} & \multicolumn{6}{|c|}{ Percentage of reduction (-) or increase (+) in lesion size ${ }^{1}$} \\
\hline & \multicolumn{6}{|c|}{$\mathrm{Time}^{2}(\mathrm{~h})$} \\
\hline & \multicolumn{3}{|c|}{ With wounding } & \multicolumn{3}{|c|}{ Without wounding } \\
\hline & 24 & 36 & 48 & 24 & 36 & 48 \\
\hline $10^{-16}$ & +3 & -27 & +6 & -16 & 00 & $-100^{*}$ \\
\hline $10^{-15}$ & +24 & +18 & -20 & -26 & 00 & -74 \\
\hline $10^{-14}$ & +32 & -36 & -8 & -14 & 00 & -74 \\
\hline $10^{-13}$ & +49 & -18 & -5 & -32 & 00 & $-94^{*}$ \\
\hline $10^{-12}$ & +38 & -55 & -16 & 00 & 00 & -70 \\
\hline $10^{-11}$ & +98 & +3 & -1 & +26 & 00 & $-90^{*}$ \\
\hline $10^{-10}$ & +89 & -12 & -54 & -26 & 00 & $-100^{*}$ \\
\hline
\end{tabular}

\footnotetext{
${ }^{1}$ Percentage of reduction (-) or increase (+) in lesion size compared to that of control.

${ }^{2}$ Time of inoculation after previous application of chemical inducer.

* Lesion size means were statistically different from controls based on Dunnett's test at $\mathrm{P}<0.10$
}

prior to inoculation with C. gloeosporioides. Over all, lesion size means were not statistically different from those of the controls according to Dunnett's test at $\mathrm{P}<0.05$.

\section{DISCUSSION}

None of the chemical compounds tested had a direct effect on C. gloeosporioides growth but apparently activated a plant response to pathogen attack as reported by Karba and Kuc (1999) and Oostendorp et al. (2001). Therefore, the resistance-inducing chemical agent apparently is as a preventive because once established, infections cannot be controlled.

Concentrations ranging from $10^{-1}$ to $10^{-4} \mathrm{M}$ of SA, INA and BA were toxic to mango leaves, resulting in necrotic areas at leaf edges and over the whole leaf. Our results on mango compare with those reported by Gorlach et al. (1996) using SA on wheat tissues. Other researchers have also reported INA toxicity when applied at high concentrations such as those tested during this study on mango leaves (Tally et al., 1999). On the basis of these findings, these compounds are not recommended for future commercial use (Kessmann et al., 1994), except for

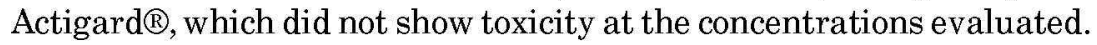

Experiments under laboratory conditions showed that individual treatments of various resistance-inducing chemical agents did result in 
TABLE 3. Percentage of reduction (-) or increase (+) in lesion size in detached mango leaves, compared to that of the controls, after the application of potential resistance-inducing chemicals at three time intervals $(24,36$ and $48 \mathrm{~h}$ ) before Colletotrichum gloeosporioides inoculation (Third Experiment).

\begin{tabular}{|c|c|c|c|c|c|c|c|c|c|c|c|c|}
\hline \multirow[b]{4}{*}{ Concentration } & \multicolumn{12}{|c|}{ Percentage of reduction (-) or increase $(+)$ in lesion size ${ }^{1}$} \\
\hline & \multicolumn{12}{|c|}{ Time $^{2}(h)$} \\
\hline & \multicolumn{4}{|c|}{24} & \multicolumn{4}{|c|}{36} & \multicolumn{4}{|c|}{48} \\
\hline & SA & INA & $\mathrm{BA}$ & A & SA & INA & $\mathrm{BA}$ & A & $\mathrm{SA}$ & INA & BA & A \\
\hline $1 \times 10^{-8}$ & +40 & -6 & -45 & -8 & +156 & +100 & +41 & $-55^{*}$ & +142 & +157 & -41 & +59 \\
\hline $1 \times 10^{-6}$ & -19 & -22 & -45 & -48 & +10 & +57 & -19 & -48 & +21 & +28 & -55 & -25 \\
\hline $1 \times 10^{-4}$ & +27 & -30 & -45 & -35 & +10 & 00 & +27 & $-55^{*}$ & 00 & +6 & +5 & -37 \\
\hline $1 \times 10^{-2}$ & +35 & -36 & -38 & -26 & -23 & +17 & +35 & $-59^{*}$ & -42 & +63 & -27 & -32 \\
\hline $1 \times 10^{-1}$ & 00 & -9 & -82 & -36 & -100 & +183 & -8 & -22 & -27 & +14 & -38 & +6 \\
\hline
\end{tabular}

Percentage of reduction or increase $(+)$ in lesion size compared to that of control.

Inoculation time after previous application of salicylic acid (SA), isonicotinic acid (INA), benzoic acid (BA) and Actigardß (A). Leaf pieces were wounded with a sterile needle before inoculation using $C$. gloeosporioides mycelial disks (4 mm).

*Lesion size means were statistically different from controls based on Dunnett's test at $\mathrm{P}<0.10$. 
TABLE 4. Percentage of reduction (-) or increase (+) in lesion size in six-month-old mango seedlings, compared to that of controls, after the application of potential resistance-inducing chemicals at three time intervals $(24,96$ and $168 \mathrm{~h})$ before Colletotrichum gloeosporioides inoculation.

\begin{tabular}{|c|c|c|c|c|c|c|c|c|c|}
\hline \multirow[b]{4}{*}{ Treatments ${ }^{3,4}$} & \multicolumn{9}{|c|}{ Percentage of reduction (-) or increase (+) in lesion size ${ }^{1}$} \\
\hline & \multicolumn{9}{|c|}{$\operatorname{Time}^{2}(\mathrm{~h})$} \\
\hline & \multicolumn{3}{|c|}{4 days } & \multicolumn{3}{|c|}{8 days } & \multicolumn{3}{|c|}{12 days } \\
\hline & 24 & 96 & 168 & 24 & 96 & 168 & 24 & 96 & 168 \\
\hline \multicolumn{10}{|l|}{ SA } \\
\hline With wounding & -6 & -9 & +3 & +5 & +11 & +34 & +18 & +4 & +17 \\
\hline Without wounding & +3 & 00 & -33 & +209 & -3 & -19 & -9 & +14 & 00 \\
\hline \multicolumn{10}{|l|}{ INA } \\
\hline With wounding & -4 & -5 & -23 & -19 & +15 & -9 & -18 & +11 & -17 \\
\hline Without wounding & -21 & +2 & -24 & +153 & +6 & -29 & -36 & -4 & -16 \\
\hline \multicolumn{10}{|l|}{ Actigard® } \\
\hline With wounding & +1 & -13 & -13 & +32 & -17 & -0.6 & +18 & -12 & +7 \\
\hline Without wounding & -31 & -64 & -29 & +267 & -78 & +26 & +3 & -60 & +9 \\
\hline \multicolumn{10}{|l|}{$\mathrm{BA}$} \\
\hline With wounding & 00 & +80 & -9 & -20 & -3 & -1 & -28 & +6 & +4 \\
\hline Without wounding & 00 & +98 & 00 & +270 & -11 & +7 & -13 & +24 & +8 \\
\hline
\end{tabular}

${ }^{1}$ Lesion size means were not statistically different from those of controls based on Dunnett's test at $\mathrm{P}<0.05$.

${ }^{2}$ Each value is the mean of two experiments, four to 12 days after inoculation with $C$. gloeosporioides. Potential resistant-inducing chemicals were sprayed on six-month-old mango seedlings at three different time intervals: 24,96 and $168 \mathrm{~h}$ before inoculation. The experiment was conducted in a shade house.

${ }^{3}$ Chemical inducers tested were $\mathrm{SA}=$ salicylic acid $10^{-7} \mathrm{M}$; INA $=$ isonicotinic acid $10^{-14}$

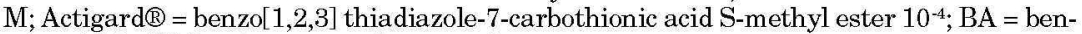
zoic acid $10^{-10} \mathrm{M}$ and water as the control.

${ }^{4}$ Tissues were inoculated with C. gloeosporioides mycelial disks $(4 \mathrm{~mm})$ with or without wounding.

significant lesion size reduction. Benzoic acid, a precursor of salicylic acid, and salicylic acid both showed reduction in lesion size caused by C. gloeosporioides, $48 \mathrm{~h}$ after application to mango tissues. These findings imply the activation or the novo synthesis of plant defenses to constrain pathogen development and to protect plant tissues in situ, or the induction of localized induced resistance. Benzoic acid showed a steady response when inoculation of $C$. gloeosporioides was done without wounding, a more natural approach to infection. Over all, lesion size of tissues treated with resistance-inducing chemicals increased when compared to lesion size of the controls.

To our knowledge there are no reports on Actigard ${ }^{\circledR}$ inducing resistance in mango tissues at the concentrations tested against $C$. gloeo- 
sporioides. Tally et al. (1999) reported that concentration of $1.2 \mathrm{mM}$ (approx. $10^{-3}$ ) is effective in the activation of genes related to inducing resistance in tobacco. However, under shade house conditions, none of the chemical inducers tested significantly reduced lesion size in mango.

Various explanations for the lack of resistance induction in mango tissues using the chemical compounds examined might be considered. First, the classical chemical inducers (i.e., salicylic acid) tested in our experiments might not produce a systemically stable induced response. In mango, we can speculate that secondary product responses, such as the production of resorcinols, are more important and critical signals for effective systemic induction (Droby et al., 1986, 1987; Hegnauer, 1993; Prusky and Keen, 1993).

Several authors have reported that investment in defense is thought to reduce the fitness of a plant, especially in enemy-free environments (Heil et al., 2000; Heil, 2001). In diseased plants, for example, young tissues (i.e., six-month-old mango seedlings) that are still growing may be unable to produce defense-related mechanisms such as pathogenesisrelated proteins (PRP) because their whole metabolic apparatus is needed for the biosynthesis of growth-relevant proteins. When induced resistance is expressed constitutively in a plant, it might incur high allocation costs (Heil, 2000; Romero et al., 2001).

Other resistance-inducing chemicals such as probenazole, jasmonic acid, cyclopropane carboxylic acid derivatives, non-protein aminoacids [ $\beta$-aminobutyric acid (BABA) and $\gamma$-aminobutyric acid (GABA)], and Phytoguard®, which have shown protection against pathogens in various economically important crops should be tested in mango tissues. These products should be evaluated individually and in combinations, to clarify this lack of induced protection in mango tissues (Jakab et al., 2001; Oostendorp et al., 2001; Pajot et al., 2001; Kessmann et al., 1994).

\section{LITERATURE CITED}

Anonymous, 2006. Ingreso Bruto Agrícola: Cifras Revisadas 2003-2004 y Cifras Preliminares 2004-2005. Agricultural Statistics Office. Department of Agriculture of Puerto Rico, San Juan, PR.

Arauz, L. F., 2000. Mango anthracnose: economic impact and current options for integrated pest management. Plant Dis. 86(6): 600-611.

Bailey, J. A. and M. J. Jeger, 1992. Colletotrichum: Biology, Pathology and Control. CABI, International, Wallingford, UK.

Colón-Garay, J., L. I. Rivera-Vargas, R. McGovern and R. del P. Rodríguez, 2002. Hypovirulent isolates of Colletotrichum gloeosporioides induce resistance to anthracnose in detached mango fruits and seedlings. J. Agric. Univ. P.R. 86(1-2):55-64.

Droby, S., D. Prusky, B. Jacoby and A. Goldman, 1987. Induction of antifungal resorcionols in flesh of unripe mango fruits and its relation to latent infection by Alternaria alternata. Physiol. Molec. Plant Path. 30:285-292. 


\section{SANTIAGO ET AL./COLLETOTRICHUM GLOEOSPORIOIDES IN MANGO}

Droby, S., D. Prusky, B. Jacoby and A. Goldman, 1986. Presence of antifungal compounds in the peel of mango fruits and their relation to latent infections of Alternaria alternata. Physiol. Molec. Plant Path. 29: 173-183.

Gorlach J., S. Volrath, G. Knauf-Beiter, H. Georges, U. Beckhove, K. Kogel, M. Oostendorp, T. Staub, E. Ward, H. Kessman and J. Ryals, 1996. Benzothiadiazole, a novel class of inducers of systemic acquired resistance, activates gene expression and disease resistance in wheat. Plant Cell 8:629-643.

Hammerschmidt, R. and J. A. Smith-Becker, 1999. The role of salicylic acid in disease resistance, pp. 37-54. In: A. Agrawal, S. Tuzun and E. Bent (eds.). Induced Plant Defenses Against Pathogens and Herbivores. APS Press, St. Paul, MN.

Hegnauer, R., 1993. Phytochemistry and chemotaxonomy of the Anacardiaceae with special emphasis on Mangifera, pp. 11-14. In: A. Kostermans and J. M. Bompard (eds.). The Mangoes: Their Botany, Nomenclature, Horticulture and Utilization. Academic Press, NY.

Heil, M., 2001. The ecological concept of costs of induced systemic resistance (ISR). Eur J. Plant Pathol. 107:137-146.

Heil, M., A. Hilpert, W. Kaiser and K.E. Linsenmair, 2000. Reduced growth and seed set following chemical induction of pathogen defense: Does systemic acquired resistance (SAR) incur allocation costs? J. Ecol. 88:645-654.

Ishii, H., Y. Tomita, T. Horio, T. Narusaka, Y. Nakazawa, K. Nishimura and S. Iwamoto, 1999. Induced resistance of acibenzolar-S-methyl (CGA 245704) to cucumber and Japanese pear diseases. Eur. J. Plant Pathol. 105:77-85.

Jakab, G., V. Cottier, V. Toquin, G. Rigoli, L. Zimmerli, J. P. Métraux and B. MauchMani, 2001. $\beta$-aminobutyric acid-induced resistance in plants. Eur. J. Plant Pathol. 107:29-37.

Karba, R. and J. Kuc, 1999. Induced resistance against pathogens and herbivores: An Overview, pp. 1-16. In: A. Agrawal, S. Tuzun and E. Bent (eds.). Induced Plant Defenses Against Pathogens and Herbivores. APS Press, St. Paul, MN.

Kessmann, H., T. Staub, C. Hofmann, T. Maetzke, J. Herzog, E. Ward, S. Uknes and J. Ryals, 1994. Induction of systemic acquired disease resistance in plants by chemicals. Annu. Rev. Phytopathol. 32:439-459.

Lugo-Noel, Y., 2001. Manejo de Colletotrichum spp. en mangó (Mangifera indica L.) mediante métodos biológicos y químicos. University of Puerto Rico-Mayagüez, M.S. Thesis. 66 pp.

Malamy, J., J. P. Carr, D. F. Klessig and I. Raskin, 1990. Salicylic acid: A likely endogenous signal in the resistance response of tobaceo to viral infection. Science 250:1002-1004.

Metraux, J. P., P. Ahi-Goy, T. Staub, J. Speich, A. Steinemann, J. Ryals and E. Ward, 1991. Induced resistance in cucumber in response to 2,6-dichloroisonicotinic acid and pathogens. Adv. Mol. Gen. of Plant-Microbe Inter. 1:432-439.

Metraux, J. P., H. Signer, J. Ryals, E. Ward, M. Wyss-Benz, J. Gaudin, K. Rashdorf, E. Schmid, W. Blum and B. Inverardi, 1990. Increase of salicylic acid at the onset of systemic acquired resistance in cucumber. Science 250:1004-1006.

Oostendorp, M., W. Kunz, B. Dietrich and T. Staub, 2001. Induced disease resistance in plants by chemicals. Eur. J. Plant Pathol. 107:19-28.

Pajot, E., D. Le Corre and D. Silué, 2001. Phytogard $®$ and DL- $\beta$-amino butyric acid (BABA) induce resistance to downy mildew (Bremia lactucae) in lettuce (Lattuca sativa L.). Eur. J. Plant Pathol. 107:861-869.

Ploetz, R. C., 1994. Anthracnose, pp. 35-36. In: R. C. Ploetz, G. A. Zentmeyer, W. T. Nishijima, K. G. Rohrbach and H. D. Ohr (eds.). Compendium of Tropical Fruit Diseases. APS Press, St. Paul, MN. 
Prusky, D. and N. Keen, 1993. Involvement of preformed antifungal compounds in the resistance of subtropical fruits to fungal decay. Plant Dis. 77(2):114-119.

Romero, A. M., C. S. Kousik and D. F. Ritchie, 2001. Resistance to bacterial spot in bell pepper induced by acibenzolar-S-methyl. Plant Dis. 85:189-194.

Tally, A., M. Oostendorp, K. Lawton, T. Staub and B. Bassi, 1999. Commercial development of elicitors of induced resistance to pathogens, pp. 357-369. In: A. Agrawal, S. Tuzun and E. Bent (eds.). Induced Plant Defenses Against Pathogens and Herbivores. APS Press, St. Paul, MN.

Uknes, S., B. Mauch-Mani, M. Moyer, S. Potter, S. Williams, S. Dincher, D. Chandler, A. Slusarenko, E. Ward and J. Ryals, 1992. Acquired resistance in Arabidopsis. Plant Cell 4:645-656.

Zhu, Y. J., M. Fitch, S. Ferreira and P. Moore, 2000. Chemically induced resistance of Carica papaya against Phytophthora palmivora. In vitro Cell Dev. Biol. Animal 36:3 (P-2065) (Abstract). 